\title{
POTENSI PERTUMBUHAN EKONOMI KOTA BITUNG
}

\author{
Jubert M. J. R. Suoth \\ Rine Kaunang \\ Lorraine. W. TH. Sondak
}

\begin{abstract}
Regional development is an integral part of national development one of benchmart for regional development is regional economic know previously the potential of a region that can be develop optimally. The asms of this study to determine the potential of the region has major effect of economic growth in Bitung cluring 2010 to 2013, and contribution of economic sector to economic growth in Bitung. This study used PDRB data Bitung City and North Sulawesi Province from 2010 to 2013. Data were obtained from the relevant agencies. Data analyted using $L Q$ analysis. The result showed that sector has $L Q>1$ is processing Industry with average $L Q 2,84$ $\%$, electricity, gas and pure water sector with average $L Q 2,22 \%$, Transportasion and Communications sector with average $L Q 1,82 \%$ and Agriculture sector with average $L Q 1,07 \%$. From the four sector showed that the four basic sector has economic strength and influence to increase economic growth in Bitung and this sector has been able to infest the needs of their own region. The industrial sector development as a basic sector, suggested to used local raw industrial, efficient and competitive and directed the development of Agriculture and fisheries industry, improving quality and economics product. The fourth development of the base sectors namely manufacturing, electricity, gas and water supply, transport and communications and agriculture sector without neglecting the development of the non base which also has the potential for the sector is developed as the financial, real estate and business services sector and the services sector expected to be able to increase the rate of economic growth Bitung.
\end{abstract}

\section{Keywords: Potential Economic Growth}

\section{ABSTRAK}

Pembangunan daerah merupakan bagian yang tidak terpisahkan dari pembangunan nasional. salah satu tolak ukur adanya pembangunan daerah adalah adanya pertumbuhan ekonomi daerah. Dalam usaha untuk meningkatkan pertumbuhan ekonmi daerah perlu diketahui terlebih dahulu potensi suatu daerah yang dapat diharapkan berkembang secara optimal. Penelitian ini merupakan salah satu upaya untuk mengetahui potensipotensi daerah yang berpengaruh besar terhadap pertumbuhan ekonomi Kota Bitung selama tahun 2010 sampai dengan tahun 2013, dan seberapa besar sumbangan sektor-sektor ekonomi terhadap pertumbuhan ekonomi Kota Bitung. Penelitian ini menggunakan data Produk Domestik Reginal Bruto (PDRB) Kota bitung dan Propinsi Sulawesi Utara tahun 2010 sampai dengan tahun 2013. Data tersebut diperoleh dari survei sekunder, yaitu dengan memanfaatkan data yang telah tersedia pada instansi terkait. Dalam skripsi ini digunakan model basis ekonomi yang tercermin pada analisis Location Quotient (LQ) yang berguna untuk mengetahui sektor-sektor basis dan non basis ekonomi. Berdasarkan hasil penelitian dengan menggunakan metode Location Quotient, sektor yang memiliki indeks LQ lebih besar dari satu dan merupakan sektor basis ekonomi adalah industri pengolahan dengan LQ rata - rata sebesar 2,84 \%, sektor listrik, gas dan air bersih dengan indeks LQ rata - rata sebasar 2,22 \%, sektor pengangkutan dan komunikasi dengan indeks LQ rata - rata sebesar 1,82 \% dan terakhir sektor pertanian dengan indeks LQ rata - rata sebesar 1,07 \%. Dari keempat hal tersebut menunjukan bahwa keempat sektor basis tersebut merupakan sektor yang memiliki kekuatan ekonomi yang cukup baik dan sangat berpengaruh terhadap peningkatan pertumbuhan ekonomi Kota Bitung serta sektor ini sudah mampu memenuhi kebutuhan daerahnya sendiri. Pengembangan sektor industri sebagai sektor basis disarankan agar terciptanya industri yang memanfaatkan bahan baku lokal, efisien dan berdaya saing, dan diarahkan pada berkembangnya industri pertanian dan perikanan, serta meningkatkan produk yang berkualitas dan ekonomis.

Pengembangan keempat sektor basis tersebut yaitu industri pengolahan, sektor listrik, gas dan air bersih, sektor pengangkutan dan komunikasi dan sektor pertanian tanpa mengabaikan pengembangan 
sektor non basis yang juga memiliki potensi untuk dikembangakan seperti sektor keuangan, real estat dan jasa perusahaan dan sektor jasa-jasa diharapkan dapat mampu meningkatkan laju pertumbuhan ekonomi Kota Bitung.

\section{Kata Kunci : Potensi Pertumbuhan Ekonomi}

\section{PENDAHULUAN}

\section{Latar Belakang}

Pembangunan ekonomi daerah adalah suatu proses dimana pemerintah daerah dan masyarakatnya mengelola sumber daya yang ada dan membentuk suatu pola kemitraan antara pemerintah daerah dengan sektor swasta untuk menciptakan suatu lapangan kerja baru dan merangsang perkembangan pertumbuhan ekonomi dalam wilayah tersebut. Dalam upaya untuk mencapai tujuan tersebut, pemerintah daerah dan masyarakatnya harus secara bersama-sama mengambil inisiatif pembangunan daerah. Pemerintah daerah beserta masyarakatnya dan dengan menggunakan sumberdaya yang ada harus mampu menaksir potensi sumberdaya yang diperlukan untuk merancang dan membangun perekonomian daerah (Arsyad, 1999).

Era otonomi telah memberikan kesempatan kepada pemerintah daerah, baik provinsi maupun kabupaten/kota untuk mengembangkan sendiri potensi daerah yang dimiliknya. Dengan kata lain, daerah diberi wewenang untuk mengelola sendiri keuangannya sekaligus menentukan arah pembangunan yang akan dilaksanakan dengan mempertimbangkan segenap potensi, sumber daya serta faktor-faktor lainnya, baik faktor pendukung maupun faktor penghambat.

Dengan demikian suatu daerah sangat memerlukan beragam data yang dapat dijadikan sebagai dasar acuan, baik dalam penyusunan evaluasi pembangunan ekonomi di daerah yang telah dilaksanakan maupun dalam perumusan perencanaan di masa yang akan datang. Pada era otonomi daerah, keberhasilan pembangunan tidak lagi hanya diukur dari kemajuan fisik yang diperoleh atau berapa besar Pendapatan Asli Daerah (PAD) yang dapat diterima. Keberhasilan pembangunan diukur dengan parameter yang lebih luas dan lebih strategis yang meliputi semua aspek kehidupan baik materil dan non materil

Setiap daerah mempunyai corak pertumbuhan yang berbeda dengan daerah lain. Oleh sebab itu perencanaan pembangunan ekonomi suatu daerah pertama-tama perlu mengenali karakter ekonomi, sosial dan fisik daerah itu sendiri, termasuk interaksinya dengan daerah lain. Tidak ada strategi pembangunan daerah yang dapat berlaku untuk semua daerah. Di pihak lain, dalam menyusun strategi pembangunan ekonomi daerah, baik jangka pendek maupun jangka dari kajian terhadap pola-pola pertumbuhan ekonomi dari berbagai wilayah, merupakan satu fakor yang cukup menentukan kualitas rencana pembangunan ekonomi daerah (Blakely, 2002).

Kota Bitung merupakan salah satu Kota yang ada di Provinsi Sulawesi Utara. Kota Bitung memiliki luas luas daratan $30.400 \mathrm{Ha}$ dan luas lautan $439,8 \mathrm{Km}$. Bitung terdiri dari 8 kecamatan dan jumlah penduduk 205.146 jiwa pada tahun 2012. Sektor pertanian dan industri merupakan sektor yang penunjang pertumbuhan ekonomi Kota Bitung.

Pertumbuhan ekonomi Kota Bitung mengalami peningkatan selama sepuluh tahun terakhir. Hal ini terlihat dari nilai PDRB yang terus meningkat dalam waktu empat tahun terakhir (2010-2013).

Peranan setiap sektor ekonomi dalam perekonomian dapat diketahui dari angka distribusi persentase Produk Domestik Regional Bruto (PDRB) Atas Dasar Harga Berlaku (ADHB). Berdasarkan Tabel 1. tersebut tampak bahwa sektor Pertanian, sektor Industri Pengolahan dan Pengangkutan/Komunikasi merupakan sektor ekonomi yang mempunyai peranan paling besar sumbangannya dalam perekonomian Kota Bitung pada tahun 20092013. Sementara itu sektor Pertambangan dan penggalian merupakan sektor ekonomi yang paling kecil sumbangannya dalam perekonomian Kota Bitung. Berdasarkan uraian diatas maka penelitian ini akan menganalisis potensi pertumbuhan ekonomi di kota Bitung pada tahun 2009-2013

Tabel. PDRB Kota Bitung Atas dasar Harga Konstan menurut Lapangan Usaha tahun 2010-2013 (Juta Rupiah). 


\begin{tabular}{|c|c|c|c|c|c|}
\hline $\begin{array}{c}\text { SEKTOR } \\
\text { EKONOMI }\end{array}$ & 2009 & 2010 & 2011 & 2012 & 2013 \\
\hline Pertanian & $\mathbf{3 4 4 , 3 2 4 . 4 7}$ & 373.820 .09 & $457,075.33$ & $486,071.72$ & $520,924.62$ \\
\hline $\begin{array}{l}\text { Tanaman Bahan } \\
\text { Makanan }\end{array}$ & $16,107.91$ & $18,102.86$ & $21,537.45$ & $22,611.95$ & $23,017.00$ \\
\hline $\begin{array}{l}\text { Tanaman } \\
\text { Perkebunan }\end{array}$ & $19,760.91$ & $20,521.80$ & $27,913.13$ & $29,530.60$ & $30,712.70$ \\
\hline $\begin{array}{l}\text { Peternakan dan } \\
\text { Hasilnya }\end{array}$ & 7,731.75 & $8,377.32$ & $10,484.13$ & $\begin{array}{l}1,524.97 \\
\end{array}$ & $11,747.74$ \\
\hline Kehutanan & 431.03 & 401.03 & 489.23 & 498.07 & 511.38 \\
\hline Perikanan & $300,292.87$ & 326.417 .07 & $396,651.40$ & $421,906.13$ & $454,965.80$ \\
\hline $\begin{array}{l}\text { Pertambangan } \\
\text { \& Penggalian }\end{array}$ & $8,458.94$ & $9,072.56$ & $15,320.68$ & $15,973.00$ & $16,565.24$ \\
\hline $\begin{array}{l}\text { Industri } \\
\text { Pengolahan }\end{array}$ & $301,691.84$ & $311,347.81$ & $517,983.55$ & $555,998.35$ & $578,159.43$ \\
\hline $\begin{array}{l}\text { Listrik, Gas \& } \\
\text { Air Bersih }\end{array}$ & $31,976.48$ & $40,765,91$ & $40,590.41$ & $44,175.58$ & $50,079.32$ \\
\hline Konstruksi & $219,776.60$ & $237,489.92$ & $335,213.99$ & $362,398.39$ & $389,473.53$ \\
\hline $\begin{array}{l}\text { Perdag, Hotel } \\
\text { \& Restoran } \\
\end{array}$ & $93,251.15$ & $100,702.64$ & $\begin{array}{l}90,693.72 \\
\end{array}$ & $208,142.57$ & $227,010.68$ \\
\hline $\begin{array}{l}\text { Pengangkutan } \\
\text { \& Komunikasi }\end{array}$ & $314,427.68$ & $335,108.90$ & $551,999.45$ & $599,535.57$ & $662,832.58$ \\
\hline $\begin{array}{l}\text { Jasa Per- } \\
\text { sewaan \& } \\
\text { Perusahaan }\end{array}$ & $\begin{array}{l}70,626.75 \\
\end{array}$ & $\begin{array}{l}74,539.81 \\
\end{array}$ & $116,342.91$ & $129,467.84$ & $147,765.93$ \\
\hline Jasa - jasa & $89,721.21$ & $\begin{array}{l}92,764.00 \\
\end{array}$ & $150,140.55$ & $163,241.04$ & $175,370.18$ \\
\hline PDRB & $1,474,255.11$ & $1,575,611.66$ & $2,375,360.59$ & $2,565,004.06$ & $2,768,211.51$ \\
\hline
\end{tabular}

Sumber : BPS Kota Bitung 2015

\section{Rumusan Masalah}

Dengan melihat dari latar belakang di atas, maka perumusan masalahnya adalah : Sektor - sektor ekonomi mana yang dapat dijadikan basis untuk di kembangkan sebagai penunjang pertumbuhan ekonomi di Kota Bitung.

\section{Tujuan Penelitian}

Tujuan penelitian adalah:

1. Mengetahui sektor basis ekonomi yang dapat meningkatkan pertumbuhan ekonomi Kota Bitung

2. Mengetahui sektor-sektor ekonomi yang potensial untuk dikembangkan sebagai penunjang pertumbuhan ekonomi di Kota Bitung

\section{Manfaat Penelitian}

Manfaat penelitian adalah memberikan informasi mengenai sektor - sektor yang menunjang ekonomi di Kota Bitung dan memberikan masukan bagi pemerintah dan investor tentang sektor-sektor ekonomi yang potensial untuk dikembangkan guna menunjang pertumbuhan ekonomi kota Bitung.

\section{Metodologi Penelitian}

\section{Lokasi dan Waktu Penelitian}

Lokasi penelitian ini di kantor BPS Kota Bitung. Penelitian ini dilaksanakan selama 2 (dua) bulan mulai dari persiapan sampai penyusunan laporan, yaitu pada bulan April sampai Mei 2015.

\section{Metode Penelitian}

Metode dasar yang digunakan dalam penelitian ini adalah metode deskriptif dan disajikan dalam bentuk tabel. Data yang akan dikumpulkan mula - mula disusun, dijelaskan dan kemudian dianalisis. Selang waktu data yang dikumpulkan yaitu dari tahun 2010 sampai tahun 2013.

\section{Jenis dan Sumber Data}

Jenis data yang digunakan dalam penelitian adalah data sekunder berupa data yang telah dikumpulkan dan dilaporkan oleh orang diluar peneliti, walau data yang dikumpulkan adalah data asli $(\mathrm{Su}-$ rakhmad, 2002). Data sekunder yang digunakan dalam penelitaian ini diperoleh dari Badan Pusat Statistik (BPS) Kota Bitung dan BPS Provinsi Sulawesi Utara.

\section{Konsep Pengukuran Variabel}

1. Laju pertumbuhan ekonomi, laju pertumbuhan ekonomi adalah kenaikan PDRB tanpa memandang apakah kenaikan itu lebih besar atau lebih kecil dari pertumbuhan penduduk, atau apakah perubahan struktur ekonomi berlaku atau tidak. Laju pertumbuhan ekonomi diukur dengan indikator perkembangan PDRB dari tahun ke tahun yang dinyatakan dalam persen per tahun.

2. Pertumbuhan ekonomi Kota Bitung 2010 - 2013, yaitu dihitung nilai tingkat pertumbuhan ekonomi selama 4 tahun $(\%)$.

3. PDRB Kota Bitung ADHK tahun 2010 - 2013, yaitu dihitung nilai PDRB Kota Bitung atas harga konstan selama 4 tahun (\%). 
4. Sektor - sektor ekonomi di Kota Bitung, yaitu sektor pembentuk angka PDRB yang berperan dalam menentukan laju pertumbuhan ekonomi.

\section{Metode Analisis Data}

1. Kontribusi Sektor - sektor Ekonomi terhadap PDRB Kota Bitung

Dalam penelitian ini digunakan data PDRB ADHK tahun 2010. Dengan rumus yaitu :

$$
\text { Kontribusi }=\frac{\text { Nilai PDRB sektor }-i}{\text { Total } P D R B} \times 100 \%
$$

2. Identifikasi Sektor Ekonomi dan sub Sektor Eko nomi

Analisis Location Quotient (LQ) digunakan untuk mengidentifikasi sektor ekonomi maupun sub sektor ekonomi di Kota Bitung. Besarnya nilai LQ dapat diperoleh dari persamaan sebagai berikut :

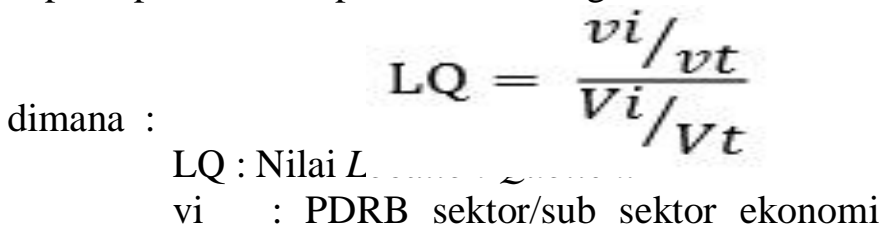
wilayah Kota Bitung

vt : PDRB total wilayah Kota Bitung

Vi : PDRB sektor/sub sektor ekonomi wilayah Provinsi SULUT

Vt : PDRB total wilayah Provinsi SULUT Kriteria :

Apabila LQ > 1 berarti sektor mauun sub sektor ekonomi merupakan sektor basis. Sedangkan LQ $\leq$ berarti sektor maupun sub sektor ekonomi merupakan sektor non basis.

3. Analisis posisi sektor ekonomi dan sub sektor ekonomi dimasa yang akan datang.

Untuk mengatasi kelemahan metode LQ digunakam varians dari metode LQ yaitu Dynamic Location Quotient (DLQ). Metode DLQ menggambarkan posisi sektor maupun sub sektor ekonomi di masa mendatang.

Dimana :

$$
\mathrm{DLQ}=\left\{\frac{(1+g i j) /(1+g j)}{(1+G i) /(1+g j)}\right\}^{t}
$$

DLQ : Indeks Dynamic Location Cuotient

gij : Rata-rata laju pertumbuhan sektor/sub sektor $\mathrm{kab} / \mathrm{kota}$
$\mathrm{Gj} \quad$ : Rata-rata laju pertumbuhan PDRB kab/kota

$\mathrm{Gi}$ : Rata-rata laju pertumbuhan sektor/sub sektor Provinsi

Gj : Rata-rata laju pertumbuhan PDRB seluruh sektor Provinsi

$\mathrm{t} \quad$ : Jumlah tahun analisis

Untuk pertumbuhan sektor/sub sektor ekonomi Kota Bitung Tahun 2011- 2013 di hitung dengan rumus :

Laju Pertumbuhan= $\left\{\frac{\text { pertumbuhan thn 2013-pertumbuhan thn } 2012}{\text { pertumbuhan thn } 2012} \times 100 \%\right\}$

Rata-rata laju pertumbuhan untuk tahun 2013 yaitu :

Gij = $\left\{\frac{\text { laju pertumbuhan 2011+ laju pertumbuhan 2012+laju pertumbuhan } 2013}{3} \times 100 \%\right\}$

Jika DLQ > 1, sektor maupun sub sektor Ekonomi masih dapat di harapkan untuk basis di masa yang akan datang. Jika DLQ $\leq 1$, sektor maupun sub sektor Ekonomi tidak dapat di harapkan untuk basis di masa yang akan datang (Suyatno, 2002).

\section{HASIL DAN PEMBAHASAN}

\section{Gambaran Umum Kota Bitung \\ Keadaan Geografis \\ Letak Geografis}

Kota Bitung sebagai salah satu Kota di Provinsi Sulawesi Utara secara geografis berada pada $10^{0} 23$ '23' '-10 $0^{0} 35^{\prime} 39$ ' Lintang Utara dan $125^{\circ} 01$ ' 43 '" $125^{\circ} 018^{\prime} 13^{\prime \prime}$ Bujur Timur. Batas - batas administrasi Kota Bitung :

Sebelah Utara : Kecamatan Likupang dan Kecamatan Dimembe (Kabupaten Minahasa Utara).

Sebelah Selatan : Laut Maluku

Sebelah Timur : Laut Maluku dan Samudera Pasifik

Sebelah Barat : Kecamatan Kauditan (Kabupaten Minahasa Utara)

Di Kota Bitung terdapat delapan buah gunung dan lima buah sungai kecil yang bermuara di Selat Lembeh, yaitu Girian, sagrat, Tanjung Merah, tewaan dan Rinondoran. 


\section{Topografi}

Dari aspek topografi, keadaan tanahnya sebagian besar daratan Bitung atau 45,06\% berombak berbukit dan $32,73 \%$ bergunung. Hanya 4,18\% merupakan daratan landai serta sisianya $18,03 \%$ berombak. Struktur tanah berpasir (Sandyclay) dengan kemiringan tanah dari dataran landai sampai bergunung dapat dibagi yaitu :

$>$ Dataran Landai dengan kemiringan ( $0-2) \%$ seluas 1.270 ha

$>$ Berombak dengan kemiringan ( 2-15 )\% seluas $5.480 \mathrm{Ha}$

Berombak berbukit dengan kemiringan ( 15-40)\% seluas $13.700 \mathrm{Ha}$

Bergunung dengan kemiringan $>40 \%$ seluas 13.700 $\mathrm{Ha}$

Di bagian Timur mulai dari pesisir pantai Aertembaga sampai dengan Tanjung Merah di bagian barat, merupakan daratan yang relatif cukup datar dengan kemiringan $0-150$, sehingga secara fisik dapat dikembangkan sebagai wilayah perkotaan, industri, perdagangan dan jasa serta pemukiman. Di bagian utara keadaan topografi semakin bergelombang dan berbukit - bukit yang merupakan kawasan pertanian, perkebunan, hutan lindung, taman margasatwa dan cagar alam. Di bagian selatan terdapat pulau lembeh yang keadaan tanahnya pada umumnya kasar ditutupi oleh tanaman kelapa, hortikultura, dan palawija. Disamping itu memiliki pesisir pantai yang indah sebagai potensi yang dapat dikembangkan menjadi daerah wisata bahari. Tata guna lahan Kota Bitung merupakan satu - satunya Kota di Sulawesi Utara dan bahkan kedua sesudah Kota Pontianak di Indonesia yang memiliki kawasan hutan yang sangat luas. (BPS Kota Bitung, 2014)

\section{Keadaan Iklim}

Kota Bitung hanya di kenal dengan dua musim, yaitu musim kemarau dan musim penghujan. Kota Bitung merupakan wilayah dengan curah hujan bervariasi. Jumlah curah hujan rata - rata di wilayah Kota Bitung berkisar antara $30-35 \mathrm{~mm} /$ tahun. Sebagai daerah tropis Kota Bitung mempunyai kelembaban udara relative tinggi dengan rata - rata perbulan pada berkisar antara $77-86 \%$ dan suhu rata - rata per bulan $24,2^{\circ} \mathrm{C}$ dan tertinggi $33,6^{\mathrm{C}}$.

\section{Luas Pengunaan Lahan}

Kota Bitung secara administratif terbagi menjadi 8 kecamatan dan terdidri 69 kelurahan. Luas wilayah daratan Kota Bitung tercatat sebesar $304 \mathrm{Km}^{2}$ dan luas lautan sebesar 439,8 Km. Dataran yang relatif datar sebesar $1.270 \mathrm{Ha}$, sehingga dapat digunakan sebagai wilayah perkotaan, industri, perdagangan dan jasa serta permukiman. Penggunaan lahan di Kota Bitung sebagian besar adalah lahan kering 99,25\%, lahan sawah $0,25 \%$ dan lainnya $0,25 \%$.

\section{Pemerintahan}

Secara admistratif wilayah Kota Bitung pada tahun 2012 terbagi 8 kecamatan. Wilayah tersebut terbagi dalam 69 kelurahan dan 2.957 rukun warga.

\section{Kependudukan \\ Penduduk}

Jumlah penduduk Kota Bitung tahun 2011 berdasarkan data hasil sensus penduduk tahun 2010 sebesar 187.652 jiwa. Dengan laju pertumbuhan rata - rata setiap tahun $3 \%$. Dilihat dari sebaran penduduk per kecamatan, sebagian besar penduduk Bitung terkonsentrasi di Kecamatan Maesa dimana 19.19 persen penduduk Bitung tinggal di kecamatan ini. Selebihnya tersebar bervariasi di setiap kecamatan. Kecamatan Madidir 17,84 persen, Kecamatan Girian 14,85 persen, Kecamatan Aertembaga 15,06 persen, Kecamatan Matuari 14,48 persen, Kecamatan Ranowulu 9,18 persen, Kecamatan Lembeh Selatan 4,83 persen dan paling sedikit di Kecamatan Lembeh Utara yang hanya 4,3 persen.

Jika dihubungkan dengan luas wilayah Kota Bitung yang $332,791 \mathrm{Km}^{2}$, maka kepadatan penduduk pada tahun 2010 mencapai sekitar 564 jiwa per kilometer persegi. Angka ini tergolong padat sebagaimana daerah perkotaan lainnya.

Tabel. Luas Wilayah, Penduduk, dan Kepadatan penduduk di Kota Bitung tahun 2010 


\begin{tabular}{|c|c|c|c|c|c|c|}
\hline \multirow{2}{*}{ Kecamatan } & \multirow{2}{*}{$\begin{array}{l}\text { Luas } \\
(\mathrm{km} 2)\end{array}$} & \multicolumn{4}{|c|}{ Penduduk } & \multirow{2}{*}{$\begin{array}{l}\text { Kepadat } \\
\text { an } \\
\text { pendud } \\
\text { uk/ }\end{array}$} \\
\hline & & $\begin{array}{l}\text { Laki- } \\
\text { laki }\end{array}$ & $\begin{array}{l}\text { Per- } \\
\text { empuan }\end{array}$ & $\begin{array}{l}\text { Jumlah } \\
(\mathrm{L}+\mathrm{P})\end{array}$ & Persen & \\
\hline Madidir & 30,45 & $\begin{array}{r}16.78 \\
8\end{array}$ & 16.694 & 33.482 & 17,84 & 1.100 \\
\hline Matuari & 36,10 & $\begin{array}{r}13.86 \\
0\end{array}$ & 13.320 & 27.180 & 14,48 & 753 \\
\hline Girian & 5,16 & $\begin{array}{r}14.20 \\
4\end{array}$ & 13.658 & 27.862 & 14,85 & 5.400 \\
\hline $\begin{array}{l}\text { Lembeh } \\
\text { Selatan }\end{array}$ & 23,53 & 4.694 & 4.426 & 9.120 & 4,86 & 388 \\
\hline $\begin{array}{l}\text { Lembeh } \\
\text { Utara }\end{array}$ & 30,62 & 4.340 & 4.169 & 8.509 & 4,53 & 278 \\
\hline $\begin{array}{l}\text { Aer- } \\
\text { tembaga }\end{array}$ & 26,12 & $\begin{array}{r}14.71 \\
9\end{array}$ & 13.543 & 28.262 & 15,06 & 1.082 \\
\hline Maesa & 9,65 & $\begin{array}{r}18.66 \\
5\end{array}$ & 17.342 & 36.007 & 19,19 & 3.731 \\
\hline Ranowulu & $\begin{array}{r}171.1 \\
7\end{array}$ & 8.731 & 8.499 & 17.320 & 9,18 & 101 \\
\hline $\begin{array}{l}\text { JUMLAH/ } \\
\text { TOTAL }\end{array}$ & $\begin{array}{r}332,7 \\
9\end{array}$ & $\begin{array}{r}96.00 \\
1\end{array}$ & 91.651 & $\begin{array}{r}187.65 \\
2\end{array}$ & 100 & 564 \\
\hline
\end{tabular}

Sumber BPS, Kota Bitung dalam angka 2014

\section{Ketenagakerjaan}

Tenaga kerja merupakan salah satu modal dalam perkembangan roda pembangunan. Jumlah dan komposisi tenaga kerja terus mengalami perubahan seiring dengan proses berlangsungnya demografi.

Berdasarkan data dari dinas ketenagakerjaan Kota Bitung angkatan kerja pada tahun 2011 banyak 88.948 orang, dengan TPAK (Tingkat Partisipasi Angkatan Kerja) sebesar 68,08 persen. TPAK menunjukan potensi sumber daya manusia yang berpartisipasi aktif dalam kegiatan ekonomi baik sebagai pekerja ataupun pencari kerja. Banyaknya pencari kerja digolongkan sebagai pengangguran terbuka. Pada tahun 2011 banyaknya pengangguran terbuka di $\mathrm{Bi}$ tung sebanyak 10.051 orang dengan kata lain tingkat pengangguran mencapai 11,30 persen. Sebagian dari pencari kerja ini terdaftar di Dinas Tenaga Kerja Kota Bitung yakni sebanyak 716 orang.

\section{Perekonomian}

Perekonomian Kota Bitung dalam perencanaan anggaran pendapatan dan belanja daerah, pemerintah tidak lagi menganut prinsip anggaran berimbang dan dinamis. Berimbang berarti harus diusahakan keseim- bangan antara penerimaan dan pengeluaran, sedangkan prinsip dinamis berarti makin meningkatnya jumlah anggaran dan tabungan pemerintah, sehingga kemampuan daerah bertambah dan ketergantungan pada bantuan keuangan dari luar daerah semakin berkurang.

Pendapatan APBD pada tahun anggaran 2012 meningkat menjadi sebesar Rp. 555.570 milyar, atau naik sebesar 13,23 persen jika dibanding tahun sebelumnya yang berjumlah Rp. 490.636 milyar. Kontribusi PAD terhadap APBD tahun anggaran 2012 sebesar 6,91 persen, naik dari tahun 2011 yang menyumbang 5,18 persen. Dari sisi belanja APBD Kota Bitung tahun 2012, porsi belanja terbesar digunakan untuk belanja Pegawai pada pos Belanja Tidak Langsung yakni mencapai 52,18 persen atau sebesar 281,03 milyar rupiah. Belanja Modal pada pos Belanja Langsung menempati posisi kedua dengan realisasi sebesar 129,16 milyar rupiah atau sebesar 23,98 persen dari total belanja APBD. (BPS Kota Bitung, 2014)

\section{Pendidikan}

Pendidikan merupakan suatu faktor kebutuhan dasar untuk setiap manusia sehingga upaya mencerdaskan kehidupan bangsa melalui pendidikan merupakan bagian dari upaya peningkatan kesejahteraan rakyat. Jika pembangunan yang dilakukan tidak dapat mengandalkan sumber daya alam yang keberadaannya terbatas maka peningkatan sumber daya manusia yang hasilnya merupakan modal untuk penggerak pembangunan.

Pemerataan kemsempatan pendidikan sangat dipengaruhi oleh tersedianya sarana dan prasarana pendidikan seperti gedung sekolah, perpustakaan, dan buku - buku penunjang pelajaran serta tenaga pendidik (guru). Fasilitas pendidikan di Kota Bitung tersedia dari tingkat TK sampai Perguruan tinggi

Bagi anak - anak pra sekolah tersedia sekolah taman kanak - kanak (TK) sebanyak 115 sekolah swasta dan negeri dengan jumlah kelas 166 kelas. Jumlah murid sebanyak 2.665 orang dan guru pengajar sebanyak 71 guru. Bagi anak - anak usia sekolah dasar (SD) terdapat 110 SD Negeri dan swasta dengan jumlah kelas sebanyak 839 kelas. Jumlah murid SD sebanyak 25.173 murid dengan mendapat bimbingan dari 275 guru. 
Banyak SMP di Kota Bitung selama tahun 2013 terdiri dari 36 sekolah negeri dan swasta dan jumlah kelas 288 kelas. Dengan jumlah siswa 9.940 siswa dan jumlah guru yang membimbing 450 Orang.

Fasilitas pendidikan untuk tingkat SMA/Sederajat lebih sedikit jika dibandingkan 2 jenjang sebelumnya terdapat 30 sekolah terdiri dari sekolah negeri dan swasta dengan jumlah kelas 310 kelas. Dapat menampung 7.676 siswa, siswan tersebut mendapat bimbingan 439 guru.

Fasilitas pendidikan lainnya di Kota Bitung berupa perguruan tinggi yaitu, Akademi Maritim Bitung (AMI), memiliki 10 ruang kelas dan dapat menampung 89 mahasiswa. Dengan mendapat bimbingan dari 18 dosen, terdiri dari 6 dosen tetap dan 12 dosen tidak tetap. STISIP MERDEKA MANADO, memiliki 4 ruang kelas dan dapat menampung 67 mahasiswa. Memiliki tenag pengajar sebanyak 16 dosen yang dapat membimbing mahasiswa tersebut. STIE PETRA BITUNG yang memiliki 10 ruang kelas dan bisa menampung sebanyak 319 mahasiswa. Mahasiswa mahasiswa tersebut mendapat bimbingan dari 39 dosen yang terdiri 23 dosen tetap dan 16 dosen tidak tetap. Banyaknya lulusan Stie Perta Bitung pada tahun 2013 adalah 96 mahasiswa. Selanjutnya ada juga STIMIK SAMUDERA BITUNG yang memiliki 5 ruang kelas dan bisa menampung 120 mahasiswa, Dengan didukung oleh 23 tenaga pengajar/dosen yang terdiri dari 15 dosen tetap dan 8 dosen tidak tetap. Dan yang terakhir AKADEMI PERIKANAN BITUNG (APB), memiliki 11 ruang kelas dan memiliki sebanyak 734 mahasiswa. Yang didukung oleh tenaga pengajar/dosen sebanyak 49 dosen yang terdiri 36 dosen tetap dan 13 dosen tidak tetap.

\section{Kesehatan}

Pembangunan di bidang kesehatan bertujuan agar semua lapisan masyarakat dapat memperoleh pelayanan kesehatan secara mudah, merata dan murah. Dengan adanya upaya tersebut diharapakan akan tercapai derajat kesehatan masyarakat yang baik dimana pada gilirannya akan meningkatkan produktivitas.

Untuk melayani masyarakat di Kota Bitung tersedia fasilitas kesehatan berupa 3 rumah sakit yang terdiri, 1 rumah sakit pemerintah, 1 rumah sakit swasta dan 1 rumah sakit TNI dengan jumlah tenaga medis sebanyak 103 dokter dan 7 apoteker. Juga terdapat 9 puskesmas, 25 puskesmas pembantu, 16 puskesmas keliling darat dan 3 puskesmas keliling laut juga tersedia 146 posyandu.'

\section{Analisis Perkembangan PDRB dan Potensi Per- tumbuhan Ekonomi}

Penelitian ini bertujuan untuk mengidentifikasi perkembangan PDRB Kota Bitung serta potensi pertumbuhan ekonomi Kota Bitung sehingga sektor sektor startegis yang potensial dapat di kembangkan untuk meningkatkan PDRB Kota Bitung. Untuk mengetahui potensi sektor - sektor ekonomi yang mendukung PDRB Kota Bitung maka digunakan alat analisis $L Q$ yaitu untuk mengetahui apakah sektor ekonomi tersebut termasuk basis atau non basis.

\section{Analisis Perkembangan PDRB}

Struktur perekonomian menggambarkan peranan atau sumbangan dari masing - masing sektor dalam perkembangan. Nilai PDRB Kota Bitung selama periode penelitian selalu mengalami peningkatan yang ditujukan oleh jumlah nominalnya yang selalu meningkat dari tahun ke tahun.

Perkembangan Produk Domestik Regional Bruto Kota Bitung seperti pada tabel di bawah dilihat dari kontribusi tiap sektornya.

Tabel. Distribusi Persentase PDRB Tahun 2010-2013 menurut Sektor Atas Harga Konstan Tahun 20102013 di Kota Bitung 
Sumber : Hasil Olahan 2015

Seperti pada table di atas sektor pertanian men-

\begin{tabular}{|c|c|c|c|c|}
\hline \multirow[t]{2}{*}{ Lapangan Usaha } & 201 & 201 & 201 & 201 \\
\hline & 0 & 1 & 2 & \\
\hline 1. PERTANIAN & $\begin{array}{r}19, \\
53\end{array}$ & $\begin{array}{r}19, \\
24\end{array}$ & $\begin{array}{c}18, \\
95\end{array}$ & $\begin{array}{r}18, \\
89\end{array}$ \\
\hline \multirow{2}{*}{$\begin{array}{l}\text { 2. PERTAMBANGAN \& } \\
\text { NGGALIAN }\end{array}$} & 0,6 & 0,6 & 0,6 & 0,5 \\
\hline & 4 & 4 & 2 & 9 \\
\hline 3. INDUSTRI PENGOLAHAN & $\begin{array}{r}21, \\
72\end{array}$ & $\begin{array}{r}21, \\
80\end{array}$ & $\begin{array}{r}21 \\
67\end{array}$ & $\begin{array}{r}20, \\
88\end{array}$ \\
\hline \multirow{2}{*}{$\begin{array}{l}\text { 4. } \\
\begin{array}{l}\text { LISTRIK, } \\
\text { \& }\end{array} \text { AIR } \quad \text { BERSIH }\end{array}$} & 1,7 & 1,7 & 1,7 & 1.8 \\
\hline & 3 & 0 & 2 & 0 \\
\hline 5. KONSTRUKSI & $\begin{array}{l}14, \\
23\end{array}$ & $\begin{array}{r}14, \\
11\end{array}$ & $\begin{array}{r}14, \\
12\end{array}$ & $\begin{array}{r}14, \\
06\end{array}$ \\
\hline \multirow{2}{*}{$\begin{array}{l}\text { 6. PERDAG., HOTEL \& } \\
\text { RESTORAN }\end{array}$} & 7,8 & 8,0 & 8,1 & 8,2 \\
\hline & 3 & 2 & 1 & 0 \\
\hline $\begin{array}{l}\text { 7. PENGANGKUTAN \& } \\
\text { MUNIKASI }\end{array}$ & $\begin{array}{r}23, \\
06\end{array}$ & $\begin{array}{r}23, \\
23\end{array}$ & $\begin{array}{r}23, \\
37\end{array}$ & $\begin{array}{r}23, \\
94\end{array}$ \\
\hline \multirow{2}{*}{$\begin{array}{lll}\text { 8. Keu. } & \text { Real } \\
\& & \text { Jasa } & \text { Perusahaan }\end{array}$} & 4,9 & 4,8 & 5,0 & 5,3 \\
\hline & 3 & 9 & 4 & 3 \\
\hline \multirow{2}{*}{ 9. JASA-JASA } & 6,3 & 6,3 & 6,3 & 6,3 \\
\hline & 0 & 2 & 6 & 3 \\
\hline DRE & 100 & 100 & 100 & 100 \\
\hline
\end{tabular}

galami penurunan dari tahun ke tahun, pada tahun 2013 kontribusinya sebesar 18,89 persen. Namun sektor pertanian masih tetap di unggulkan di bandingkan sektor - sektor lainnya yang kontribusinya relatif kecil. Sektor penggalian dan Pertambangan umumnya juga mengalami penurunan dari tahun ke tahun, pada tahun 2013 kontribusinya 0,59 persen. Industri pengolahan juga mengalami penurunan dari tahun ke tahun, pada tahun 2013 kontribusinya turun menjadi 20,88 persen. Kontribusi terbesar terjadi pada sub sektor industri bukan migas yaitu makanan, Minuman dan Tembakau. Produk yang dihasilkan oleh kegiatan industri yaitu produk tepung tapioca dan ikan sardine (ikan kaleng ). Produk ini banyak di minati oleh masyarakat dan laku di pasaran. Sehingga memberikan kontribusi yang cukup besar terhadap PDRB dan ekonomi Kota Bitung.

Sektor listrik, Gas \& Air bersih mengalami kenaikan dari tahun, pada tahun 2013 kontribusinya sebesar 1,80 persen Untuk sektor ini kontribusi terbesarnya pada sub sektor listrik. Sektor Kontruksi mengalami penurunan dari tahun ke tahun, pada tahun 2013 kontribusinya menjadi 14,06 persen. Sektor
Perdagangan mengalami kenaikan dari tahun ke tahun, pada tahun 2010 kontribusinya 7,83 persen dan pada tahun 2013 naik kontribusinya menjadi 8,20 persen. Sektor Pengangkutan juga mengalami kenaikan dari tahun ke tahun, pada tahun 2013 kontribusinya sebesar 23,94 persen. tersedianya pelabuhan container dan pelabuhan samudaera yang membuat Kota Bitung memiliki aksebilitas yang baik dan semakin terbuka dengan kota - kota di Indonesia yang dapat menunjang perekonomian Kota Bitung. Sehingga kontribusinya pada PDRB ikut meningkat. Sektor Real Estat dan jasa Perusahaan juga mengalami kenaikan dari tahun ke tahun, pada tahun 2013 kontribusinya sebesar 5,33 persen. Juga demikian dengan sektor Jasa jasa mengalami ke naikan walaupun hanya relatif kecil, pada tahun 2013 kontribusinya sebesar 6,33 persen.

Dari table di atas bisa dilihat kontribusi PDRB terbesar terdapat pada sektor pengangkutan dan komunikasi dengan besar nilai 23,94 persen, di ikuti oleh sektor industri pengolahan 20,88 persen dan sektor pertanian besar nilai 18,89 persen. Dengan demikian maka ke tiga sektor ini berpotensi menjadi penunjang pertumbuhan ekonomi di Kota Bitung.

\section{A. Laju Petumbuhan Ekonomi Kota Bitung}

Perkembangan laju pertumbuhan ekonomi Kota Bitung bisa dilihat cepat atau lambatnya pertumbuhan ekonomi. Lajunya peningkatan dari sektor Gas, Listrik \& Air bersih pada tahun 2010 sebesar 3,3 persen meningkat tinggi pada tahun 2013 sebesar 13,3 persen dan sektor keuangan, real estat dan jasa perusahaan pada tahun 2010 sebesar 5,6 persen dan meningkat pada tahun 2013 sebesar 14,1 persen. Bisa dilihat pada table dibawah ini 
Tabel. Laju Pertumbuhan Ekonomi Tahun 20102013 Di Kota Bitung sektor tersebut masing - masing mengalami penurunan dalam 4 tahun terakhir.

Pada sektor listrik, gas \& air bersih, sektor kon-

\begin{tabular}{|c|c|c|c|c|}
\hline Lapangan Usaha & 2010 & 2011 & 2012 & 2013 \\
\hline 1. PERTANIAN & 7,9 & 6,1 & 6,3 & 7,1 \\
\hline $\begin{array}{l}2 . \\
\text { TAMBANGAN \& PENGGALIAN }\end{array}$ & 7,5 & 8,0 & 4,2 & 3,7 \\
\hline 3. INDUSTRI PENGO LAHAN & 8,4 & 8,1 & 7,3 & 3,9 \\
\hline 4. LISTRIK, GAS \& AIR BERSIH & 3,3 & 6,0 & 8,8 & 13,3 \\
\hline 5. KONSTRUKSI & 4,8 & 6,8 & 8,1 & 7,4 \\
\hline 6. PERDAG., HOTEL \& RESTORAN & 7,9 & 10,4 & 9,1 & 7,4 \\
\hline $\begin{array}{l}\text { 7. PENGANGKUTAN \& KOMU- } \\
\text { NIKASI }\end{array}$ & 6,3 & 8,5 & 8,6 & 10,5 \\
\hline $\begin{array}{l}\text { 8. KEU. REAL ESTAT, \& JASA PE- } \\
\text { RUSAHAAN }\end{array}$ & 5,6 & 6,9 & 11,2 & 14,1 \\
\hline 9. JASA-JASA & 5,8 & 8,0 & 8,7 & 7,4 \\
\hline PDRB & 6,8 & 7,7 & 7,9 & 7,9 \\
\hline
\end{tabular}
struksi, sektor pengangkutan dan komunikasi, sektor real estat dan jasa perusahan dan sektor jasa - jasa mengalami kenaikan. Kenaikan yang terjadi pada sektor listrik, gas \& air bersih adalah 3,3 persen pada tahun 2010 dan pada tahun 2013 adalah 13,3 persen. Sektor konstruksi dan sektor pengangkutan dan komunikasi juga mengalami kenaikan, masing - masing, pada tahun 2010 adalah 4,8 persen dan pada tahun 2013 sebesar 7,4 peren, dan pada tahun 2010 sebesar 6,3 persen dan pada tahun 2013 sebesar 0,105 persen untuk sektor pengangkutan dan komunikasi. Sektor real estate dan jasa perusahaan pada tahun 2010 sebesar 5,6 dan pada tahun 2013 sebesar 14,1 persen. Juga pada sektor jasa jasa pada tahun 2010 sebesar 5,8 persen dan Sumber : Hasil Olahan 2015

Pertumbuhan ekonomi Kota Bitung pada setiap sektor PDRB terjadi berbeda- beda, ada sektor yang mengalami kenaikan ada sektor yang mengalami penurunan. Seperti pada sektor pertanian mengalami penurunan dari 7,9 persen pada tahun 2010, turun menjadi 7,1 persen pada tahun 2013. Penurunan sektor pertanian karena semakin padatnya penduduk $\mathrm{d}$ kota Bitung sehingga banyak lahan pertanian dialih fungsikan ke lahan pemukiman. Selain itu sub sektor perikanan juga menurun kontribusinya ke sektor pertanian disebabkan karena banyak ikan hasil tangkapan yang di ekspor berupa bahan baku dan bukan produk jadi. Begitu juga sektor - sektor lainnya, sektor pertambangan \& penggalian pada tahun 2010 sebesar 7,5 persen dan pada tahun 2013 sebesar 3,7 persen. Hal ini disebabkan banyaknya ijin galian yang di tutup karena mengganggu lingkungan. Industri pengolahan pada tahun 2010 sebesar 8,4 persen dan pada tahun 2013 turun menjadi 3,9 persen, dan sektor perdagangan, hotel dan restoran mengalami juga hal yang sama pada tahun 2010 sebesar 7,9 menjadi 7,4 pada tahun 2013, tetapi pada sektor perdagangan, hotel dan restoran tidak terlalu besar atau masih relatif kecil penurunannya dibandingkan pada sektor pertambangan \& penggalian dan industri pengolahan yang mengalami penurunan relatif besar. Ke empat pada tahun 2013sebesar 7,4 persen. Kenaikan terbesar terjadi pada sektor listrik, gas dan air bersih dan sektor real estat dan jasa perusahaan.

Pada keseluruhan PDRB sektor ekomoni di Kota Bitung mengalami kenaiakan dari tahun ke tahun. Dengan demikian pertumbuhan ekonomi di Kota Bitung juga mengalami kenaikan tiap tahunnya dari tahun 2010 sebesar 6,8 persen dan pada tahun 2013 sebesar 7,9 persen.

\section{Analisis Potensi Pertumbuhan Sektor Ekonomi Analisis Location Quotient (LQ)}

Analisis Locaton Quetiont ( $L Q)$ digunakan untuk mengetahui sektor- sektor ekonomi manakah yang termasuk sektor basis atau berpotensi ekspor dan manakah yang termasuk bukan merupakan sektor basis. Hal tersebut dapat terlihat jika $L Q$ menunjukan angka lebih dari satu $(L Q>1)$ berarti sektor tersebut merupakan sektor basis. Kemudian jika hasil menunjukan angka kurang dari satu $(L Q<1)$ berarti sektor tersebut bukan merupakan sektor basis. 
Table.8. Nilai LQ menurut sektor di Kota Bitung

\begin{tabular}{|c|c|c|c|c|c|}
\hline Lapangan Usaha & 2010 & 2011 & 2012 & 2013 & $\begin{array}{l}\text { LQ } \\
\text { rata } \\
- \\
\text { rata }\end{array}$ \\
\hline 1. PERTANIAN & $\begin{array}{l}1,07 \\
\text { (b) }\end{array}$ & $\begin{array}{l}1,06 \\
\text { (b) }\end{array}$ & $\begin{array}{l}1,07 \\
\text { (b) }\end{array}$ & $\begin{array}{l}1,09 \\
\text { (b) }\end{array}$ & $\begin{array}{l}1,07 \\
\text { (b) }\end{array}$ \\
\hline $\begin{array}{l}\text { 2. PERTAMBANGAN } \\
\& \text { PENGGALIAN }\end{array}$ & $\begin{array}{l}0,13 \\
(\mathrm{nb})\end{array}$ & $\begin{array}{l}0,12 \\
(\mathrm{nb})\end{array}$ & $\begin{array}{l}0,12 \\
(\mathrm{nb})\end{array}$ & $\begin{array}{l}0,12 \\
(\mathrm{nb})\end{array}$ & $\begin{array}{l}0,12 \\
(\mathrm{nb})\end{array}$ \\
\hline $\begin{array}{l}\text { 3. INDUSTRI PEN- } \\
\text { GOLAHAN }\end{array}$ & $\begin{array}{c}2,93 \\
\text { (b) }\end{array}$ & $\begin{array}{l}2,78 \\
\text { (b) }\end{array}$ & $\begin{array}{c}2,83 \\
\text { (b) }\end{array}$ & $\begin{array}{l}2,82 \\
\text { (b) }\end{array}$ & $\begin{array}{c}2,84 \\
\text { (b) }\end{array}$ \\
\hline $\begin{array}{l}\text { 4. LISTRIK, GAS \& } \\
\text { AIR BERSIH }\end{array}$ & $\begin{array}{l}2,35 \\
\text { (b) }\end{array}$ & $\begin{array}{l}2,20 \\
\text { (b) }\end{array}$ & $\begin{array}{l}2,20 \\
\text { (b) }\end{array}$ & $\begin{array}{l}2,16 \\
\text { (b) }\end{array}$ & $\begin{array}{c}2,22 \\
\text { (b) }\end{array}$ \\
\hline 5. KONSTRUKSI & $\begin{array}{l}1,00 \\
\text { (b) }\end{array}$ & $\begin{array}{l}0,88 \\
(\mathrm{nb})\end{array}$ & $\begin{array}{l}0,86 \\
(\mathrm{nb})\end{array}$ & $\begin{array}{l}0,88 \\
(\mathrm{nb})\end{array}$ & $\begin{array}{l}0,90 \\
(\mathrm{nb})\end{array}$ \\
\hline $\begin{array}{l}\text { 6. PERDAG., HOTEL } \\
\& \text { RESTORAN }\end{array}$ & $\begin{array}{l}0,51 \\
(\mathrm{nb})\end{array}$ & $\begin{array}{l}0,45 \\
(\mathrm{nb})\end{array}$ & $\begin{array}{l}0,45 \\
(\mathrm{nb})\end{array}$ & $\begin{array}{l}0,44 \\
(\mathrm{nb})\end{array}$ & $\begin{array}{l}0,46 \\
(\mathrm{nb})\end{array}$ \\
\hline $\begin{array}{l}\text { 7. PENGANGKUTAN } \\
\& \text { KOMUNIKASI }\end{array}$ & $\begin{array}{l}1,87 \\
\text { (b) }\end{array}$ & $\begin{array}{l}1,77 \\
\text { (b) }\end{array}$ & $\begin{array}{l}1,80 \\
\text { (b) }\end{array}$ & $\begin{array}{l}1,86 \\
\text { (b) }\end{array}$ & $\begin{array}{c}1,82 \\
\text { (b) }\end{array}$ \\
\hline $\begin{array}{l}\text { 8. KEU. REAL ESTAT, } \\
\& \quad \text { JASA PERUSAHAAN }\end{array}$ & $\begin{array}{l}0,79 \\
(\mathrm{nb})\end{array}$ & $\begin{array}{l}0,72 \\
(\mathrm{nb})\end{array}$ & $\begin{array}{l}0,73 \\
(\mathrm{nb})\end{array}$ & $\begin{array}{l}0,72 \\
(\mathrm{nb})\end{array}$ & $\begin{array}{l}0,74 \\
(\mathrm{nb})\end{array}$ \\
\hline 9. JASA-JASA & $\begin{array}{l}0,44 \\
(\mathrm{nb})\end{array}$ & $\begin{array}{l}0,41 \\
(\mathrm{nb})\end{array}$ & $\begin{array}{l}0,41 \\
(\mathrm{nb})\end{array}$ & $\begin{array}{l}0,41 \\
(\mathrm{nb})\end{array}$ & $\begin{array}{l}0,41 \\
(\mathrm{nb})\end{array}$ \\
\hline
\end{tabular}

Sumber : Hasil Olahan 2015

Keterangan : (b) : Sektor Basis dan

(nb) : Sektor Non Basis

Berdasarkan table diatas, Kota Bitung memilik 4 sektor basis, sektor tersebut yaitu sektor industri pengolahan dengan indeks $L Q$ rata - rata sebesar 2,84. Sektor industri pengolahan merupakan yang memiliki kekuatan ekonomi yang cukup baik di Kota Bitung karena memiliki perusahan industri yang baik dan berkembang pesat. Pertumbuhan industri didaerah ini sangat pesat sehingga menjadi kekuatan ekonomi bagi Kota Bitung. Beragam jsenis produk dihasilkan oleh kegiatan industri yang ada. Produk - produk tersebut adalah tepung tapioca dan ikan sardine (ikan kaleng) yang dapat menunjang pertumbuhan ekonomi Kota Bitung. Industri pengolahan di Kota Bitung yaitu PT. Nabati Sulawesi Utara yang bergerak di bidang industry minyak goreng dengan berbahan baku dari kelapa, PT. Sari Kelapa juga industry yang bergerak di bidang minyak goreng dan tepung terigu. PT. Indofood yang bergerak dibidang mie instant.

Sektor basis terbesar kedua dengan indeks $L Q$ rata - rata sebasar 2,22 adalah sektor listrik, gas dan air bersih. Denagn bertamabahnya penduduk dan terjadi Pembangunan melalui perumahan - perumahan dan pembanguan perusahan - perusahan industri di kota Bitung tumbuh seiring dengan pesatnya kegiatan industri dan pemukiman yang telah ada. Sektor ini ini tumbuh seiring dengan aktivitas manusia yang menuntut tersedianya kebutuhan primer dan sekunder, hal ini dapat terlihat dengan menjamurnya perusahan - perusahan besar serta pusat - pusat perdagangan lainnya di Kota Bitung. Pada tahun 2013 jumlah daya listrik yang terpasang selama setahun 88.165.450 VA dengan rata-rata perbulan sebesar 7.347.120,83 VA dan daya yang tersalurkan selama setahun 88.165 .450 VA dengan rata-rata perbulan sebesar 7.347.120,83 VA. Serta listrik terjual selama setahun sebesar 11.624.257 VA. Jumlah ini dibagi masing - masing pelanggan, seperti sosial sebesar 1.905.050 VA pertahun dan rata-rata perbulan 158.754,16 VA, rumah tangga sebesar 33.327.150 VA pertahun dan rata-rata perbulan 2.777.262,5 VA, usaha sebesar 25.273.350 VA pertahun dan rata-rata perbulan 2.106.112,5 VA, kantor atau gedung sebesar 2.235.600 VA pertahun dan rata-rata perbulan $186.300 \mathrm{VA}$, dan industri sebesar 25.279.300 VA pertahun dan rata-rata perbulan 2.106.608,33 VA.

Sektor basis terbesar ketiga dengan indeks $L Q$ rata - rata sebesar 1,82 adalah sektor pengangkutan dan komunikasi. Sumbangan terbesar dari sektor ini terjadi pada sub sektornya yaitu sub sektor Angkutan Laut. Angkutan laut merupakan sarana perhubungan yang penting bagi Indonesia mengingat Indonesia merupakan Negara kepulauan. Sektor ini merupakan sektor yang memiliki kekuatan ekonomi yang cukup baik di Kota Bitung karena tersedianya pelabuhan container (peti kemas) dan pelabuhan samudera yang membuat Kota Bitung memiliki aksebilitas yang baik dan semakin terbuka dengan kota - kota di Indonesia. Pelabuhan Bitung adalah pelabuhan alam di Kota Bitung, yang merupakan pelabuhan terbesar satu satunya pelabuhan di Sulawesi utara yang disinggahi oleh kapal-kapal penumpang antar kota besar di Indonesia. Adanya pelabuhan Bitung merupakan salah satu faktor yang mendorong dan dapat menunjang pertumbuhan perekonomian dan perkembangan Kota Bitung, selain dari kegiatan perkebunan, pertanian dan perikanan. Jumlah kapal yang masuk pelabuhan pelabuhan Bitung tahun 2013 adalah 3,630 buah kapal, turun sebesar 35,11 persen dari tahun 2012. Kapal 
yang singgah adalah kapal luar negeri 2,59 persen, kapal pelayaran dalam negeri 66,56 persen, kapal pelayaran khusus 5,29 persen, kapal pelayaran rakyat 17,38 persen, serta sisanya 8,18 persen pelayaran perintis. Dan jumlah barang yang dibongkar tahun 2013 5.686.806 ton, naik dari tahun sebelumnya yang 3.067.473 ton. Begitu juga barang yang dimuat pada tahun 2013 sebanyak 3.609.313 ton, naik dari tahun sebelumnya 1.329.160 ton. Dari keseluruhan barang yang dibongkar sebagian besar merupakan barang pelayaran dalam negeri sebanyak 5,629.943 ton atau 99,00 persen. Sedangkan untuk muat barang, sebagian besar muatan barang dalam negeri sebanyak 2.971.810 ton atau sebesar 82,34 persen. Dan jumlah penumpang turun/naik mengalami penurunan dari 229.414 orang tahun 2012 menjadi 140.735 orang pada tahun 2013. Sebagian besar penumpang naik/turun merupakan penumpang dalam negeri. Untuk lebih jelas inilah sebagian dari kapal-kapal yang singgah di pelabuhan Bitung, KM. Sinabung merupakan kapal penumpang yang berasal dari pulau jawa dngan tahun pembuatan 1997 dan pelabuhan pendaftaran adalah pelabuhan Bitung (Sulut) dengan kapasitas muatan sekitar 1.906 orang yang dibagi dalam beberapa kelas yaitu kelas 1 sebanyak 144 orang, kelas 2 sebanyak 364 orang, kelas 3 sebanyak 594 orang dan kelas ekonomi 804 orang. Kapal ini masuk atau sandar di pelabuhan Bitung 2 kali dalam sebulan atau setiap 2 minggu sekali masuk pelabuhan Bitung. Kemudian KM. Tilongkabila juga merupakan kapal penumpang yang berasal dari pulau jawa dengan tahun pembuatan 1994 dan pelabuhan pendaftaran adalah pelabuhan Tanjung Priok (Jakarta). Kapal ini memiliki kapasitas muatan sekitar 970 orang dengan masing - masing kelas, yaitu kelas 1 sebanyak 14 orang, kelas 2 sebanyak 40 orang dan kelas ekonomi sebanyak 916 orang. Kapal ini juga masuk atau sandar di pelabuhan Bitung 2 kali dalam sebulan atau setiap 2 minggu sekali masuk pelabuhan Bitung. Beriktnya KM. Dorolonda adalah kapal yang berasal dari Palu dan pelabuhan Luwuk (Sulteng). Kapal ini hanya mampung menampung 200 sampai 500 orang. Kapal ini singgah di pelabuhan Bitung sebanyak 2 kali dalam sebulan. Selanjutnya ada kapal pengakut barang (peti kemas) yang juga singgah di pelabuhan bitung, seperti kapal Maersk Alabama merupakan kapal pengangukut barang yang berasal dari Amerika ini memiliki daya angkut sebanyak 1.092 container sekali bongkar muat dengan lama pemindahan container 1x24 jam dengan menggunakan crant. kapal ini memiliki sebanyak 20 awak kapal, kebanyak awak kapal adalah waraga Negara Amerika. Kapal ini masuk atau sandar di pelabuhan peti kemas Bitung sebanyak 2 kali dalam sebulan atu bisa hanya sekali dalam sebulan. Kapal ini merupakan kapal barang terbesar yang sandar di pelabuhan peti kemas Bitung.

Sektor yang juga merupakan sektor basis adalah pertanian dengan nilai rata - rata $L Q$ sebesar 1,07. Kontribusi hasil pertanian cukup baik terhadap pertumbuhan ekonomi Kota Bitung. Hasil Tanaman perkebunan memliki hasil yaitu tanaman Kelapa dalam, Kelapa Hibrida, Cengkeh, Pala, Coklat dan Jambu Menteh. Pada tahun 2013 hasil tanaman kelapa yang cukup besar di beberapa kecamatan di Kota Bitung seperti di sebagian kecamatan Matuari, kecamatan Ranowulu dan sebagian yang ada di kecamatan Aertembaga. Seperti Kelapa dalam denagn luas areal sebesar 13.279,5 Ha dengan jumlah pohon sebanyak 1.327.950 pohon dengan hasil produksi sebesar 5.006,46 ton, dan Kelapa Hibrida denagn luas areal sebesar 33,6 Ha dengan jumlah pohon sebanyak 33.600 pohon dan jumlah produksi sebanyak 470,4 ton. Hasil produksi dari tanaman Kelapa ini seperti natadecoco dan minyak Bimoli yang di sukai dan menjadi bahan masakan pokok masyarakat sehingga mampu bersaing di pasaran, Dengan begitu kontribusi sektor ini pada PDRB pun meningkat. Tanaman Cengkeh memiliki hasil produksi sebanyak 21,65 ton dari luas areal sebesar 170,61 Ha dan jumlah pohon sebanyak 17.060 pohon. Hasil tanaman cengkeh bisa digunakan untuk kesehatan dan sebagai bahan baku pembuatan rokok. Tanaman Coklat memiliki hasil produksi sebanyak 2,31 ton dari luas areal sebesar 22,25 Ha dan jumlah pohon sebanyak 4.929 pohon. Tanaman Pala memiliki hasil produksi sebanyak 53,81 ton dari luas areal sebesar 541,25 $\mathrm{Ha}$ dan jumlah pohon sebanyak 54.200 pohon. Hasil tanaman Pala bisa dibuat manisan. Tanaman Jambu Menteh memiliki hasil produksi sebanyak 1,61 ton dari luas areal sebesar 8,5 Ha dan jumlah pohon sebanyak 600 pohon. Hasil produksi tersebut dapat menunjang pertumbuhan ekonomi Kota Bitung.

Dari keempat hal tersebut menunjukan bahwa keempat sektor basis tersebut merupakan sektor yang memiliki kekuatan ekonomi yang cukup baik dan sangat berpengaruh terhadap peningkatan pertum- 
buhan ekonomi Kota Bitung serta sektor ini sudah mampu memenuhi kebutuhan daerahnya sendiri.

Sektor yang merupakan sektor bukan basis selama periode tahun 2010-2013 terdapat 5 sektor yaitu sektor pertambagan dan penggalian dengan $L Q$ rata - rata sebesar 0,12 , sektor perdagangan, hotel dan restoran $L Q$ rata - rata sebesar 0,46 , sektor keuangan, real estat dan jasa perusahaan $L Q$ rata - rata sebesar 0,74 dan sektor jasa - jasa $L Q$ rata - rata sebesar 0,41.

Walaupun sektor basis merupakan sektor yang paling potensial untuk dikembangkan dan untuk memacu pertumbuhan ekonomi Kota Bitung, sektor non basis harus dikembangkan untuk menjadi sektor basis baru ditunjang dengan adanya sektor basis yang telah ada.

\section{Perubahan Posisi Sektor Berdasarkan Nilai LQ dan DLQ}

Perubahan Posisi Sektor Berdasarkan Nilai LQ dan DLQ dapat dilihat pada Tabel Berikut

\begin{tabular}{|c|c|c|c|}
\hline Lapangan Usaha & $\mathbf{L Q}$ & $\begin{array}{c}\mathbf{D L} \\
\mathbf{Q}\end{array}$ & $\begin{array}{c}\text { Ket- } \\
\text { erangan }\end{array}$ \\
\hline 1. PERTANIAN & $\begin{array}{c}1,0 \\
7\end{array}$ & 1,02 & Basis - Basis \\
\hline $\begin{array}{l}\text { 2. PERTAMBANGAN } \\
\& \quad \text { PENGGALIAN }\end{array}$ & $\begin{array}{c}0,1 \\
2\end{array}$ & 0,96 & $\begin{array}{l}\text { Non Basis- } \\
\text { Non Basis }\end{array}$ \\
\hline $\begin{array}{l}\text { 3. INDUSTRI PEN- } \\
\text { GOLAHAN }\end{array}$ & $\begin{array}{c}2,8 \\
4\end{array}$ & 1,06 & Basis - Basis \\
\hline $\begin{array}{l}\text { 4. LISTRIK, GAS \& } \\
\text { AIR BERSIH }\end{array}$ & $\begin{array}{c}2,2 \\
2\end{array}$ & 0,99 & $\begin{array}{l}\text { Basis - Non } \\
\text { Basis }\end{array}$ \\
\hline 5. KONSTRUKSI & $\begin{array}{c}0,9 \\
0\end{array}$ & 0,93 & $\begin{array}{l}\text { Non Basis- } \\
\text { Non Basis }\end{array}$ \\
\hline $\begin{array}{l}\text { 6. PERDAG., HOTEL } \\
\& \quad \text { RESTORAN }\end{array}$ & $\begin{array}{c}0,4 \\
6\end{array}$ & 0,91 & $\begin{array}{l}\text { Non Basis- } \\
\text { Non Basis }\end{array}$ \\
\hline $\begin{array}{l}\text { 7. PENGANGKUTAN } \\
\& \text { KOMUNIKASI }\end{array}$ & $\begin{array}{c}1,8 \\
2\end{array}$ & 1,12 & Basis - Basis \\
\hline $\begin{array}{l}\text { 8. KEU. REAL ESTAT, } \\
\& \text { JASA PERUSAHAAN }\end{array}$ & $\begin{array}{c}0,7 \\
4\end{array}$ & 0,97 & $\begin{array}{l}\text { Non Basis- } \\
\text { Non Basis }\end{array}$ \\
\hline 9. JASA-JASA & $\begin{array}{c}0,4 \\
1\end{array}$ & 1,00 & $\begin{array}{l}\text { Non Basis - } \\
\text { Basis }\end{array}$ \\
\hline
\end{tabular}

Sumber : Hasil Olahan 2015
Pada Table 9 posisi sektor Ekonomi Kota Bitung. Sektor Pertanian, sektor Industri Pengolahan dan sektor Pengangkutan dan Komunikasi tidak mengalami perubahan, tetap menjadi sektor basis karena PDRB sektor pertanian stabil dari tahun 2010-2013 dengan nilai LQ > 1 setiap tahunnya. Pada Sektor Listrik, Gas dan Air mengalami perubahan yang awalnya menjdi sektor basis berubah menjadi non basis karena nilai PDRB sektor Listrik, Gas dan Air tidak stabil dengan nilai LQ $<1$, disebabkan kerena dengan adanya banyak pembangunan-pembangunan seperti pembangunan perumahan-perumhan, perusahaan-perusahaan dan pembangunan lainnya di Kota Bitung yang membuat daya listrik, Gas dan Air bersih mengurang dan tidak mampu memenuhi kebutuhan dati masyarakat Kota Bitung

Namun pada sektor Pertambangan dan Penggalian, sektor Konstruksi, dan sektor Keuangan, Real Estat dan Jasa Perusahan yang tidak mengalami perubahan karena nilai LQ $<1$ sehingga tetap pada posisi sektor non basis namun dapat diharapkan menjadi sektor basis di masa yang akan datang. Namun pada sektor Jasa-jasa mengalami perubahan dari non basis menjadi basis karena nilai LQ $>1$, disebabkan karena dengan bertambahnya penduduk Kota Bitung, maka kebutuhan masyarakat seperti kesehatan, makanan, uang, dan lain-lain juga bertambah. Maka jasa-jasa seperti jasa Bank dan jasa kesehatan juga ikut bertamabah. Sektor Industri Pengolahan, sektor Pengangkutan dan Komunikasi serta sektor Pertanian menjadi penunjang dalam perekonomian Kota Bitung. Hal ini disebabkan karena ketiga sektor tersebut memberikan kontribusi yang baik dalam mendorong pertumbuhan ekonomi sehingga kinerja perekonomian daerah akan meningkat. 
Tabel. Sektor Ekonomi Berdasarkan Posisi sumber : Data Hasil Olahan 2015

Table di atas menjelaskan pengelompokan sektor berdasarkan perubahan posisi ekonomi di Kota Bitung. Dapat dilihat posisi sektor Pertanian tetap berada di posisi basis, namun mengalami penurunan karena sub sektor perikanan yang penyumbang terbesar mengalami peurunan karena hasil penjualan atau produksi perikanan tidak masuk ke daerah.

Sektor Pertambangan dan Penggalian tidak mengalami perubahan tetap berada pada posisinya, namun mengalami kenaikan yang disebabkan dengan adanya pengggalian $\mathrm{C}$ yang ada di daerah Kota $\mathrm{Bi}$ tung.

Sektor Industri Pengolahan tidak mengalami perubahan tetap berada pada posisinya, namun mengalami penurunan karena perusahaan industri pengolahan PT. Bimoli yang bergerak di bidang Minyak Goreng, hanya menyediakan bahan bakunya saja, tidak melakukan produksi dan proses produksi di lakukan di daerah lain.

Sektor Keuangan, Real Estat dan jasa Perusahaan tidak mengalami perubahan tetap berada pada posisinya, namun mengalami kenaikan dengan adanya pembangunan dibidang perumahan dan pembangunan perusahaan industri di Kota Bitung yang membuat terserapnya banyak tenaga kerja.

Perubahan posisi sektor yang terjadi dari Sektor Listrik, Gas \& Air Bersih dari basis menjadi non basis, disebabkan kerena dengan adanya banyak pembangunan-pembangunan seperti pembangunan perumahan-perumhan, perusahaan-perusahaan dan pembangunan lainnya di Kota Bitung yang membuat daya listrik, Gas dan Air bersih mengurang dan Tidak mampu memenuhi kebutuhan dari masyarakat

Kota

Bitung.

Sektor Perdagangan, Hotel dan Restoran tidak mengalami perubahan tetap berada pada posisinya, namun mengalami kenaikan yang disebabkan dengan adanya pelabuhan penumpang dan container serta banyaknya perusahaan industri ini membuat perdagangan dan restoran di Kota Bitung meningkat.

Sektor Pengangkutan dan Komunikasi tidak mengalami perubahan tetap berada pada posisinya, karena Sumbangan terbesar dari sektor ini terjadi pada sub sektornya yaitu sub sektor Angkutan Laut. Angkutan laut merupakan sarana perhubungan yang penting bagi Indonesia mengingat Indonesia merupa- kan Negara kepulauan. Sektor ini merupakan sektor

\begin{tabular}{lll}
\hline $\begin{array}{l}\text { Yang akan } \\
\text { datang }\end{array}$ & & \\
& Basis & Non Basis
\end{tabular}

Sekarang

\begin{tabular}{llll}
\hline Basis & Sektor & Pertanian, & Sektor Listrik, Gas \\
& $\begin{array}{l}\text { Sektor Industri Pen- } \\
\text { golahan, }\end{array}$ \& Air, \\
& $\begin{array}{l}\text { Pektor } \\
\text { Pengangukutan \& }\end{array}$ & \\
& Komunikasi, & \\
\hline Non Basis & Sektor Jasa-jasa & sektor r Per- \\
& & tambangan r \\
& & penggalian, sektor \\
& & Konstruksi, sektor \\
& & Perdagangan, hotel \\
& & \& Restoran, sektor \\
& & Keungan, Real \\
& & Estat \& Jasa Perus- \\
& & ahaan, Jasa \\
\hline
\end{tabular}

yang memiliki kekuatan ekonomi yang cukup baik di Kota Bitung karena tersedianya pelabuhan container (peti kemas) dan pelabuhan samudera yang membuat Kota Bitung memiliki aksebilitas yang baik dan semakin terbuka dengan kota - kota di Indonesia. Pelabuhan Bitung adalah pelabuhan alam di Kota Bitung, yang merupakan pelabuhan terbesar satu satunya pelabuhan di Sulawesi utara yang disinggahi oleh kapal-kapal penumpang antar kota besar di Indonesia. Adanya pelabuhan Bitung merupakan salah satu faktor yang mendorong dan dapat menunjang pertumbuhan perekonomian dan perkembangan Kota Bitung, selain dari kegiatan perkebunan, pertanian dan perikanan.

Perubahan posisi sektor Jasa-jasa dari non basis menjadi basis. Karena dengan bertamabahnya penduduk Kota Bitung, maka kebutuhan masyarakat seperti kesehatan, makanan, uang, dan lain-lain juga bertambah. Maka jasa-jasa seperti jasa Bank dan jasa kesehatan juga ikut bertamabah.

\section{PENUTUP}

\section{KESIMPULAN}

1. Kontribusi masing-masing sektor Produk Domestik Regional Bruto Kota Bitung selama 4 tahun dari tahun 2010 samapai 2013 mengalami peningkatan yang ditunjukan oleh jumlah nominalnya yang mengalami peningkatan dari tahun ke tahun. 
2. Sektor Industri Pengolahan, Sektor Listrik, Gas dan Air Bersih, Sektor Pengangkutan dan Komunikasi dan Sektor Pertanian memiliki nilai sumbangan tertinggi dalam perkembangan PDRB Kota Bitung. Selain itu keempat sektor tersebut juga merupakan sektor basis ekonomi yang berpotensi meningkatkan pertumbuhan ekonomi wilayah Kota Bitung karena memiliki nilai LQ lebih dari satu. Sektor Industri Pengolahan dengan LQ rata rata sebesar 2,84 persen, Sektor Listirk, Gas dan Air Bersih dengan LQ rata - rata sebesar 2,22 persen, Sektor Pengangkutan dan Komunikasi dengan LQ rata - rata sebesar 1,82 persen dan Sektor Pertanian dengan LQ rata - rata sebesar 1,07 persen.

3. Selain keempat sektor basis di atas sektor Ekonomi lainnya seperti, sektor Listrik, Gas dan Air Bersih, dan sektor Jasa-jasa juga potensial untuk dapat dikembangkan sebagai penunjang pertumbuhan ekonomi Kota $\mathrm{Bi}$ tung. Dilihat dari hasil perhitungan DLQ sektor tersebut.

\section{Saran}

1. Pemerintah Kota Bitung dapat lebih memperhatikan untuk sektor basis yang mampu menunjang pertumbuhan ekonomi mengingat dimasa akan datang sektor basis akan mengalami perubahan posisi.

2. Pemerintah Kota Bitung diharapkan dapat merumuskan strategi pengembangan di sektor Pertanian, Sektor Industri Pengolahan dan Sektor Pengangkutan dan Komunikasi serta sektor Listrik, Gas dan Air Bersih. Namun tidak mengabaikan sektor-sektor non basis, kerena dengan meningkatkan pengembangan dari sektor non basis dapat bertummbuh menjadi sektor basis dan mampu mendukung pertumbuhan ekonomi Kota Bitung.

\section{DAFTAR PUSTAKA}

Arsyad, Lincoln, 1999. Pengantar bangunan Ekonomi. STIE YKPN. Jakarta.
Blakely and Bradshaw, 2002. Planning Local Economic Development. Theory and Practice. Sage Publication, London, New Delhi.

Boediono, 1999. Teori Pertumbuhan Ekonomi. BPFE - UGM. Yogyakarta.

Badan Pusat Statistik, 2014. Bitung dalam angka. BPS. Kota Bitung.

2014. Letak Geografis Kota Bitung.BPS. Kota Bitung. , 2014. Produk Domestik Regional Bruto Kota Bitung Menurut Lapangan Usaha. BPS. Kota Bitung.

Budiharsono, S. 2005. Teknik Pengembangan Wilayah Pesisir Dan Lautan. PT. Pradnya Paramita. Jakarta.

Darwanto, 2006. Prinsip Dasar bangunan Ekonomi daerah.

Glasson, 2000. Pengantar Perencanaan Regional bagian Satu dan Dua (terjemahan Paul Sitohang). Lembaga Penerbit FEUI. Jakarta.

Irawan dan Suparmako, 2002. Pembangunan Ekonomi. BPFE. Yogyakarta.

Jhingan, 2012. Ekonomi Pembangunan dan Perencanaan. PT Raja Grafindo. Persada, Jakarta.

Makridakris, 1999. Teori PDRB. USU. Medan.

Martono, 2000. Ekonomi Pembangunan. Universitas Sebelas Maret, Surakrta.

Riyadi dan Bratakusuma. 2005. Perencanaan Pembangunan Daerah. Gramedia. Jakarta.

Todaro, 2005. Pembangunan Ekonomi di Dunia Keti ga, Penerbit Erlangga. Jakarta.

-------, 2006. Pembangunan Ekonomi Edisi Kesembi lan Jilid Satu. Erlangga. Jakarta.

Tarigan, R., 2004. Ekonomi Regional Teori dan Apli kasi.) PT. Bumi Aksara, Jakarta. ., 2005. Ekonomi Regional Teori dan Aplikasi. (edisi revisi) PT. Bumi Aksara, Jakarta.

., 2007. Ekonomi Regional Teori dan Apli kasi.PT. Bumi Aksara, Jakarta.

Sukirno, S. 1985. Ekonomi Pembangunan. Jakarta: LP FEUI.

Sukirno, S. 1996. Pengantar Teori Makro Ekonomi. Jakarta: PT raja Grafindo Persada.

Surakhmad, 2002. Pengantar Penelitian Ilmiah. Tar sito. Bandung. 
Suryana Drs, 2000. Ekonomi Pembangunan Problematika dan Pendekatan. Jakarta. Salemba Empat.

Suparmoko, 2002. Ekonomi Publik Untuk Keuangan Dan Pembangunan DaerahYogyakarta. 